\title{
Communication
}

\author{
[Comunicação]
}

\section{Bubaline mastitis etiology in Northeast of Brazil}

\author{
[Etiologia da mastite bubalina no Nordeste do Brasil] \\ E.S. Medeiros ${ }^{1}$, M.F.L. Freitas ${ }^{2}$, J.W. Pinheiro Júnior ${ }^{3}$, T.N. Saukas ${ }^{1}$, C.C. Krewer ${ }^{1}$, \\ A.S. Santos ${ }^{1}$, M.M. Costa ${ }^{4}$, R.A. Mota ${ }^{1 *}$ \\ ${ }^{1}$ Universidade Federal Rural de Pernambuco - Recife, PE \\ ${ }^{2}$ Universidade Federal de Pernambuco - Vitória, PE \\ ${ }^{3}$ Universidade Federal Rural de Pernambuco - Garanhuns, PE \\ ${ }^{4}$ Universidade Federal do Vale do São Francisco - Petrolina, PE
}

\begin{abstract}
According to FAO (Food and Agriculture Organization), buffaloes are the most docile animals in the planet, being useful to meat and milk production as well as work in several areas of the world. The Brazilian herd is composed by three Indian breeds (Murrah, Jafarabadi and Carabao) and one European breed (Mediterranean) introduced in Marajó island, Pará state, in 1895 (Silva et al., 2003).
\end{abstract}

The bubaline herds present the same sanitary problems as bovine ones and among the infectious diseases, mastitis has a strong association with economic losses due drop in milk production and costs with therapy and prevention. The inflammatory process of mammary gland can reduce the nutritive value of milk and compromise the production (Carvalho et al., 2007). Considering the few studies about bubaline mastitis etiology in Brazil, the aims of the present study were to evaluate clinical and subclinical mastitis frequency, as well as the etiology of bubaline mammary glands infections in herds from Northeast of Brazil.

A total of 1,896 milk samples from 474 bubaline females were analyzed. The animals were raised in four farms from Pernambuco, Alagoas, Bahia and Ceará states. The animals had different ages and were Murrah or crossbred. The buffaloes were raised under intensive or semi-intensive management and submitted to mechanical milking.
After the physical examination of the mammary gland, lacteous secretion was submitted to strip cup test (Blood and Radostits, 1991) and CMT (Schalm and Noorlander, 1957). The samples classified as ++ and +++ scores in CMT and the positive samples in strip cup test were collected to microbiological examination after the teat disinfection using ethanol $70^{\circ} \mathrm{GL}$. The samples were transported in isothermal boxes to the laboratory.

Aliquots of $10 \mu \mathrm{L}$ of milk were streaked onto $5 \%$ ovine blood agar and Sabouraud agar and incubated at $37^{\circ} \mathrm{C}$ for $24 \mathrm{~h}, 48 \mathrm{~h}$ and $72 \mathrm{~h}$. The morphological characteristics of the colonies (size, color and hemolysis) were observed, as well as the morphological and Gram stain characteristics of the bacterial cells (Quinn et al., 1994). The biochemical tests employed to Staphylococcus spp. classification were free coagulase production and DNAse, catalase and acetoin production and glucose (anaerobiosis) and mannitol (aerobiosis and anaerobiosis) fermentation proves. The isolates belonging to Enterobacteriaceae family were classified using the following biochemical tests: urease production, triple sugar iron agar reactions, methil red/Voges-Proskauer, SIM (sulfideindole-motility) agar reactions and citrate utilization (Quinn et al., 1994). The statistical analyses of absolute and relative frequency were performed according to Sampaio (1998) descriptions.

Recebido em 12 de julho de 2012

Aceito em 30 de julho de 2013

* Autor para correspondência (corresponding author)

E-mail: rinaldo.mota@hotmail.com 
In the CMT test, 802 out of 1,896 milk samples $(42.2 \%)$ were classified as,+++ or +++ scores. The percentage of positive scores were $18.0 \%$ to ++ score, $16.2 \%$ to +++ score and $8.0 \%$ to + score. The isolated microorganisms from clinical and subclinical bubaline mastitis are presented in Tab. 1. From 1,896 analyzed samples, 90/1,896 (4.7\%) demonstrated clinical mastitis by strip cup test and from these 19/1,896 (1.0\%) had chronic mastitis with tissue atrophy, whose milk collection for microbiological culture was not possible. From clinical mastitis, fifty one milk samples $(71.8 \%, 51 / 71)$ were positive in bacteriological analysis. The most prevalent bacteria were Staphylococcus spp. (42.2\%), followed by Corynebacterium spp. (11.3\%) and Gram negative bacteria $(5.6 \%)$.

Table 1. Isolated microorganisms from clinical and subclinical mastitis cases in bubaline herds from Northeast of Brazil

\begin{tabular}{lcc}
\hline Microorganisms & A.F. & R.F. \\
\hline Staphylococcus spp. & 185 & 49,4 \\
Streptococcus spp. & 14 & 3,7 \\
Corynebacterium spp. & 87 & 23,2 \\
Micrococcus spp. & 07 & 1,8 \\
Bacillus spp. & 02 & 0,5 \\
Candida spp. & 03 & 0,8 \\
Gram negative & 62 & 16,5 \\
Mixed infections & & 2,1 \\
Staphylococcus spp. + Corynebacterium spp. & 08 & 0,5 \\
Corynebacterium spp. + Gram negative & 02 & 2,1 \\
Staphylococcus spp. + Gram negative & 08 & 0,2 \\
Corynebacterium spp. + Micrococcus spp. & 01 & 0,2 \\
Gram negative + Bacillus spp. & 01 & 0,2 \\
Staphylococcus spp. + Bacillus spp. & 01 & 0,2 \\
Staphylococcus spp. + Candida spp. & 01 & \\
Total (1) & 374 & \\
\hline
\end{tabular}

A.F. - Absolut frequency; R.F. - Relative frequency;

(1) - Considering that a same animal can carry more than one bacterium only the numbers used to percentual determination are adopted.

When the Brazilian states were analyzed, in Pernambuco, from 256 milk samples, 31 were positive in CMT and 29 showed bacterial growth. The most frequent etiologic agent was Staphylococcus spp., being one coagulase positive staphylococcus (CPS) and 12 coagulase negative staphylococci (CNS). In Alagoas state, from 392 samples, 24 were associated to clinical mastitis and 17 were positive for bacteriologic culture. From 121 positive samples in CMT, 77 demonstrated growth on microbiologic culture. The most identified genus was Staphylococcus spp., being two CPS and 54 CNS. In Bahia, from 960 milk samples, clinical mastitis was associated to 62 and 31 samples were positive for bacteriologic culture. From 300 positive samples in CMT test 197 presented bacterial growth. Once again Staphylococcus spp. was the most frequent microorganism, being three $S$. aureus, $34 \mathrm{CPS}$ and $70 \mathrm{CNS}$. In Ceará, from 288 analyzed samples, four were associated to clinical mastitis, being isolated bacteria from one of them. In CMT positive samples $(n=228), 101$ were also positive in the culture. Gram-negative bacteria were more prevalent in bubaline mastitis in Ceará state, being identified Escherichia coli $(\mathrm{n}=25)$ and Klebsiella spp. $(\mathrm{n}=8)$. For this state, all Staphylococcus spp. isolates were classified as CNS.

From 651 positive samples in CMT in all studied properties, $330(50.7 \%)$ were positive on microbiologic culture. The most identified genus was Staphylococcus spp. (23.8\%), followed by Corynebacterium spp. (11.7\%) and Gram negative bacteria $(9.0 \%)$.

The early diagnosis of mastitis is very important to reduce economic losses and increase the success in treatment of diseased animals (Kapronezai et al., 2005). CMT is a very useful test to detection of subclinical mastitis in cattle. 
Considering the lower levels of somatic cells counts for buffaloes when compared to cows, the use of CMT test may be controversial to a precise mastitis diagnosis in bubaline. (Oliveira et al., 2004).

Studies about bubaline mastitis are not common when compared to cattle and few animals are evaluated in these surveys (Cunha et al., 2006; Dhakal et al., 2007). In Northeast of Brazil, studies were generally designed in a punctual manner, what demonstrates the importance of the more thorough researches like here. In Pernambuco, Cunha et al. (2006) evaluated 128 bubaline females and observed $5.47 \%$ clinical cases and $41.41 \%$ subclinical cases. In São Paulo state, Costa et al. (2000) evaluated 778 bubaline female and found a clinical mastitis prevalence of $0.44 \%$ and subclinical mastitis of $7.15 \%$. Kapronezai et al. (2005) detected only one $(0.4 \%)$ positive milk sample in strip cup test and $3.8 \%$ of the samples were associated to subclinical mastitis in buffaloes. These results are according to those observed in this study since subclinical cases were more frequent than clinical ones.

In Ceará state, coliform bacteria were associated to clinical and subclinical mastitis. Mastitis by coliform may present several clinical signs of udder infection with some systemic reactions (Dhakal et al., 2007). Some factors can be associated to higher incidences of Gram negative bacteria in Ceará like reflux of disinfectant in pre and post-dipping and the use of not treated water to clean teats and facilities. Buffaloes were carried under semi-intensive systems that permit to spread Gram negative pathogens from the environment.

In farms from Pernambuco, Alagoas and Bahia states, the most frequent isolated bacteria were Staphylococcus spp. From 203 Staphylococcus spp. isolates, $1.5 \%(3 / 203)$ was identified as $S$. aureus, $18.2 \%(37 / 203)$ as CPS and $80.3 \%$ $(163 / 203)$ as CNS. Other Brazilian studies reported that Staphylococcus spp. are the most frequent etiologic agent of buffaloes mastitis (Kapronezai et al., 2005; Cunha et al., 2006). These bacteria are transmitted especially during the milking and are very important to understand the epidemiology of bubaline mastitis (Taponen and Pyörälä, 2009).
The relevance of CNS in intramammary infection has increased in recent years. These agents were considered with low importance in infectious process of mammary glands. However, Oliveira et al. (2004) stressed the increase in bubaline mastitis caused by CNS. This high prevalence is found in this study. CNS becomes the most prevalent etiologic agent of udder infection in cattle in some countries. Although with middle clinical signs, these pathogens are more persistent in the udder, as well as associated to high economic losses by drop in milk quality and quantity (Taponen and Pyörälä, 2009).

The sources of CNS are unclear and the bacteria may be found in teat canals, skin and other extramammary sites (Taponen and Pyörälä, 2009). Several studies have concluded that the major transmission route of Staphylococcus spp. is the milker hands by poorly milking hygiene habits and fails in sanitization of equipments. Health education measures about the critical control points must be adopted with the goal of reducing Staphylococcus spp. prevalence in the herds (Costa et al., 2000). In all bubaline milking farms from this study where Staphylococcus spp. were the most prevalent pathogens, critical points were identified as problems in pre and post-dipping; failure in milk equipments maintenance, no trained milker; poorly hygiene in milking parlour; failures in sanitization of equipment and absence of milking order.

Other important milk pathogens were isolated from bubaline females. Corynebacterium spp. and Streptococcus spp. were more prevalent than those described by Dhakal et al. (2007). Candida spp. was isolated in $0.8 \%$ of milk samples. Micotic mastitis by Aspergillus fumigatus in buffalo was reported in Brazil and was associated to previous antibacterial treatment (Oliveira et al., 2004).

The results of this study show a high subclinical mastitis frequency in bubaline herds from Northeast of Brazil. The most prevalent bacteria were CNS.

Keywords: milk, mammary gland, buffaloes, microorganisms 


\section{RESUMO}

Este estudo teve como objetivo avaliar a frequência de mastite clínica e subclínica e descrever os microorganismos envolvidos no processo inflamatório da glândula mamária nos rebanhos de búfalos leiteiros no Nordeste do Brasil. Foram analisadas 1.896 amostras de leite provenientes de 474 búfalos em quatro propriedades localizadas nos Estados de Alagoas, Bahia, Ceará e Pernambuco. Após o exame físico da glândula mamária, as amostras de leite de cada teto foram submetidas aos testes da caneca do fundo preto e CMT (California Mastitis Test). As amostras que apresentaram scores $++e+++$ no CMT e as positivas para a caneca do fundo preto foram submetidas ao exame microbiológico. Do total de amostras estudadas, 90/1.896 (4,74\%) apresentaram mastite clínica. Com relação ao CMT, observou-se que 802/1.896 (42,2\%) das amostras demonstraram mastite subclínica. Staphylococcus spp. foram os microorganismos mais frequentes, seguidos de Corynebacterium spp. e bactérias gram-negativas. Os resultados obtidos neste trabalho demonstram uma elevada prevalência de mastite subclínica em rebanhos bubalinos no Nordeste do Brasil, especialmente causadas por Staphylococcus coagulase negativa $(S C N)$. Recomenda-se que o processo de ordenha seja aprimorado, incluindo melhorias na higiene e treinamento de ordenhadores, a fim de reduzir a frequência da doença nos rebanhos.

Palavras-chave: leite, glândula mamária, búfalos, micro-organismos

\section{REFERENCES}

BLOOD, D.C.; RADOSTITS, O.M. Veterinary Medicine. 7.ed. London: Baillière Tindall, 1991. $1224 \mathrm{p}$.

CARVALHO, L.B.; AMARAL, F.R.; BRITO, M.A.V.P. et al. Contagem de células somáticas e isolamento de agentes causadores de mastite em búfalas (Bubalus bubalis). Arq. Bras. Med. Vet. Zootec., v.59, p.242-245, 2007.

COSTA, E.O.; WATANABE, E.T.; RIBEIRO, A.R. et al. Mastite bubalina: etiologia, índices de mastite clínica e subclínica. Napgama, v.3, p.312-315, 2000.

CUNHA, A.P.; SILVA, L.B.G.; PINHEIRO JÚNIOR, J.W. et al. Perfil de sensibilidade antimicrobiana de agentes contagiosos e ambientais isolados de mastite clínica e subclínica de búfalas. Arq. Inst. Biol., v.73, p.1721, 2006.

DHAKAL, I.P.; DHAKAL, P.; KOSHIHARA, T.; NAGAHATA, H. Epidemiological and bacteriological survey of buffalo mastitis in Nepal. J. Vet. Med. Sci., v.69, p.1241-1245, 2007.

KAPRONEZAI, J.; MELVILLE, P.; BENITES, N.R. Análise microbiológica, teste de Tamis e California Mastitis Test realizados em amostras de leite de fêmeas bubalinas pertencentes a rebanhos do Estado de São Paulo. Arq. Inst. Biol., v.72, p.183-187, 2005.
OLIVEIRA, M.V.V.; MOTA, R.A.; OLIVEIRA, A.A.F. et al. Utilização do Whiteside Modificado e California Mastitis Test no diagnóstico da mastite subclínica em búfalas e sua relação com o exame microbiológico. Rev. Cienc. Anim., v.14, p.39-45, 2004.

QUINN, P.J.; CARTER, M.E.; MARKEY, B.; CARTER, G. Clinical Veterinary Microbiology. London: Wolfe, 1994. 648p.

SAMPAIO, I.B.M. Estatística aplicada à experimentação animal. Belo Horizonte: Fundação de Ensino e Pesquisa em Medicina Veterinária e Zootecnia, 1998. 221p.

SCHALM, O.W.; NOORLANDER, D.O. Experimental and observations leading to development of the california mastitis test. J. Am. Vet. Med. Assoc., v.130, p.199-204, 1957.

SILVA, M.S.T.; LOURENÇO JR, J.B.; MIRANDA, H.A. et al. Programa de incentivo à criação de búfalos por pequenos produtores, PRONAF-Pará, 2003. Belém: CPATU, 2003.20p.

TAPONEN, S.; PYÖRÄLÄ, S. Coagulasenegative staphylococci as cause of bovine mastitis-not so different from Staphylococcus aureus? Vet. Microb., v.134, p.29-36, 2009. 